

\title{
Substructure formation during Cu2o single crystal creep
}

\author{
E. Fries, A. Audouard, T. Bretheau
}

\section{To cite this version:}

E. Fries, A. Audouard, T. Bretheau. Substructure formation during Cu2o single crystal creep. Revue de Physique Appliquée, 1978, 13 (10), pp.489-493. 10.1051/rphysap:019780013010048900 . jpa00244479

\section{HAL Id: jpa-00244479 https://hal.science/jpa-00244479}

Submitted on 1 Jan 1978

HAL is a multi-disciplinary open access archive for the deposit and dissemination of scientific research documents, whether they are published or not. The documents may come from teaching and research institutions in France or abroad, or from public or private research centers.
L'archive ouverte pluridisciplinaire HAL, est destinée au dépôt et à la diffusion de documents scientifiques de niveau recherche, publiés ou non, émanant des établissements d'enseignement et de recherche français ou étrangers, des laboratoires publics ou privés. 


\title{
SUBSTRUCTURE FORMATION DURING $\mathrm{Cu}_{2} \mathrm{O}$ SINGLE CRYSTAL CREEP
}

\author{
E. FRIES, A. AUDOUARD and T. BRETHEAU \\ Laboratoire de Physique des Matériaux, C.N.R.S. Bellevue \\ 92190 Meudon, France
}

(Reçu le 17 mars 1978, révisé le 21 juin 1978, accepté le 21 juin 1978)

\begin{abstract}
Résumé. - Des monocristaux d'oxyde cuivreux $\mathrm{Cu}_{2} \mathrm{O}$ ont été déformés de $2 \%$ à $50 \%$ par compression à haute température. La force a été appliquée parallèlement à $\langle 100\rangle$ et à $\langle 110\rangle$. La topographie de rayons $\mathrm{X}$ de Berg-Barrett a montré l'existence de rotations de réseau autour de deux axes dans le premier cas et d'un seul axe dans le second cas. Les sous-structures de fluage également révélées par attaque chimique sont différentes dans les deux cas :

1) Quand la force est appliquée parallèlement à $\langle 100\rangle$, la structure est identique sur tout l'échantillon dès le début du fluage transitoire ; elle se transforme progressivement en une structure cellulaire équiaxe bien définie à l'état stationnaire.

2) Quand la force est appliquée parallèlement à $\langle 110\rangle$ la structure est différente. Elle présente divers aspects sur les différentes parties de l'échantillon au cours du fluage transitoire et se transforme en une structure cellulaire uniforme biaxe à l'état stationnaire; les joints des cellules sont parallèles aux directions $\langle 100\rangle$. La sous-structure de fluage est en étroite corrélation avec la déformation locale dans l'éprouvette de compression.
\end{abstract}

\begin{abstract}
Cuprous oxide single crystals $\mathrm{Cu}_{2} \mathrm{O}$ have been deformed from $2 \%$ to $50 \%$ in high temperature compression. The stress was parallelto $\langle 100\rangle$ and $\langle 110\rangle$. X-ray Berg-Barrett topography showed the occurence of lattice rotations around two axes in the former case and around one axis in the latter case. Creep substructures, also investigated by chemical etch pitting, were different in both cases :

1) When the stress was parallel to $\langle 100\rangle$ a dense structure with the same features all over the sample in the early stage of the transient creep gradually turned to a well defined equiaxed cell structure in the steady state creep.

2) When the stress was parallel to $\langle 110\rangle$ a quite different structure with different features in different parts of the sample in the transient creep turned to a uniform biaxed cell structure with cell boundaries parallel to the $\langle 100\rangle$ directions in the steady state creep. A strong correlation was observed between substructure and local deformation within the compression specimen.
\end{abstract}

1. Introduction. - Plastic properties of cuprous oxide have been investigated at low and high temperature [1, 2]. Compression creep tests have been performed and have shown different plastic behaviour when the stress is applied along $\langle 100\rangle$ or $\langle 110\rangle$. The creep curves (strain rate versus true strain) are very dissimilar : glide elements, strain distribution and structure were studied to understand this. An analysis of the glide elements particularly the Burgers vectors is now in progress by transmission electron microscopy. A macroscopic study of the strain distribution has been made by Bretheau et Dolin [3] to estimate the heterogeneity of the deformation. Fries et al. [4] have studied, by Berg-Barrett topography and chemical etching, lattice rotations and cell structure when the stress is applied parallel to the $\langle 100\rangle$ direction. In this paper, we present results on the structure of samples when the stress is applied parallel to the $\langle 110\rangle$ direction and we compare the behaviour of both kinds of deformed samples.

2. Experimental procedure. -2.1 Preparation AND MECHANICAL TESTS. - Specimen preparation and creep machine have already been described elsewhere $[5,6]$. The samples are $2.5 \times 2.5 \times 6$ $( \pm 0.1) \mathrm{mm}^{3}$ parallelepipeds. Two types of samples are used : C samples (Fig. 1a) crept in compression along the [001] axis and CX samples (Fig. 1b) crept in compression along the [110] axis. The applied stresses are $1000 \mathrm{~g} / \mathrm{mm}^{2}(10 \mathrm{MPa})$ and 150 to $350 \mathrm{~g} / \mathrm{mm}^{2}$ (1.5 to $3.5 \mathrm{MPa}$ ) respectively for the C and CX samples at $800{ }^{\circ} \mathrm{C}$. Microstructure obser- 

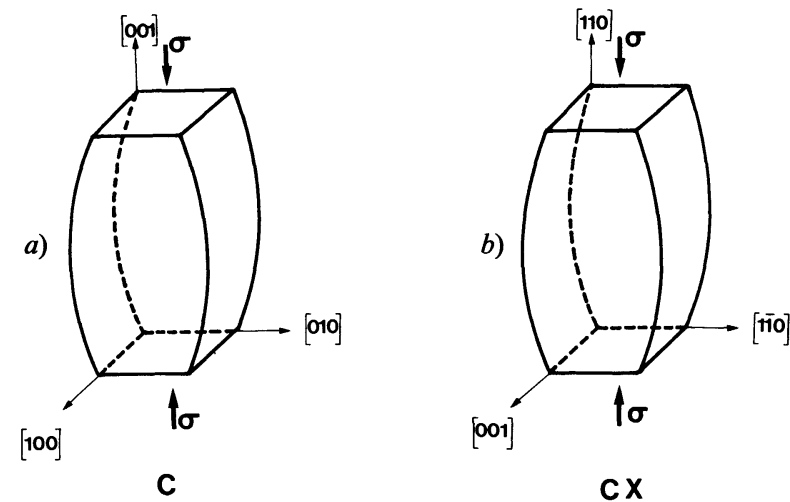

FIG. 1. - Reference axes of $\mathrm{Cu}_{2} \mathrm{O}$ samples : [001] growth axis a) $\mathrm{C}$ sample ; $b$ ) CX sample.

vations were performed on the same sample in the $2 \%-30 \%$ deformation range for the $\mathrm{C}$ and $5 \%$ $50 \%$ for the CX. The tests were repeated on various samples.

2.2 Microstructural OBServations. - 2.2.1 Berg-Barrett topography. - We have observed by Berg-Barrett X-ray topography described in [7, 8], the dislocation substructure and the resultant lattice rotations. We used $\mathrm{CuK} \alpha$ radiation and $\{200\}$ or $\{400\}$ reflecting planes to examine $\{100\}$ faces, and $(2 \overline{2} 0)$ reflecting planes to examine $(1 \overline{1} 0)$ faces. The photographic plate was parallel to the incident beam and not to the specimen surface, thus giving rise to an horizontal distorsion of $0.53,0.72$ and 0.58 for the $\{200\},\{400\}$ and (2) 0$)$ reflecting planes respectively. The horizontal divergence of the X-ray beam was about $24^{\prime}$.

We have recalled the different types of BergBarrett contrasts in a previous paper [4] : the main axes used to exhibit a rotation (rotation contrast) or to measure the angle of rotation (displacement contrast) are respectively vertical and horizontal in our experiments as well as in our topographs.

2.2.2 Etch pitting. - The etching is not easy, when successfull it has been checked by Berg-Barrett topography. It can be made in a few seconds on a chemically polished sample with

$$
70 \% \mathrm{H}_{3} \mathrm{PO}_{4}+30 \% \mathrm{HNO}_{3} .
$$

But a lot of parameters interferes : crystalline orientation; former thermal treatment, true local strain... In the present case the etching on a $\{100\}$ face is much easier than the etching on a $\{110\}$ face; but it is not always very uniform even on the same face. The observation of the dislocation substructure is made by optical reflexion microscopy.

3. Results. - 3.1 BERG-BARRETT TOPOGRAPHY. Both kinds of samples exhibit a macroscopic plane strain with two barelled faces (Fig. 1) ; in the CX case the (001) is the plane face [3]. Results about initial substructure as well as deformation of $\mathrm{C}$ samples have already been published [4] and are recalled here :

- the initial substructure is made of subgrains $1 \mathrm{~mm}$ width elongated along the [001] growth axis, misorientated approximately $1^{0}$ around this axis. Inside them we observe cells of about $300 \mu \mathrm{m}$ with a rotation smaller than the beam divergence, i.e. 24 '. Subgrains are gradually rotating during the creep, while in place of the initial cells new cells are developed within these subgrains. We focus our interest on the substructure and misorientation within the subgrain.

- Berg-Barrett topography of deformed C samples showed a rotation around two independant axes : a main rotation around the [100] axis and a minor rotation around the [010] axis. A stable microstructure was associated with the change from the transient to the steady state creep [2].

We shall now consider the deformed CX samples : an observation of two orthogonal faces of various samples during creep shows a rotation around the [001] axis only. Figures $2 a$ and $b$ represent the same sample : the plane face (001) (Fig. 2a) shows no rotation contrast (no rotation around the [1히 axis) and clearly exhibits a cellular structure; the cell boundaries are parallel to $\langle 100\rangle$ and imaged by displacement contrast due to rotation around the

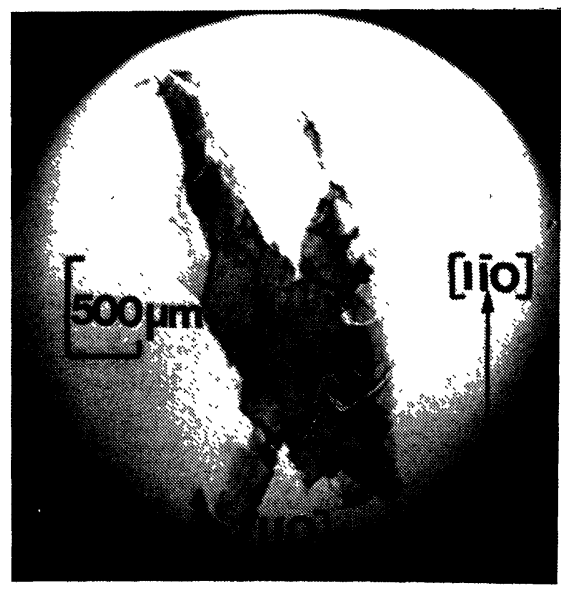

a)



b)

FIG. 2. - Berg-Barrett topographs of a $30^{\circ}$ " strained ( $X$ sample a) $(001)$ plane face, $[004]=\mathbf{g} ; b)(1 \overline{1} 0)$ bent face, $[2 \overline{2} 0]=\mathbf{g}$. 
[110] axis. The bent face (110) (Fig. $2 b$ ) shows no rotation contrast because this rotation around the [110] axis is smaller than the beam divergence $\left(24^{\prime}\right)$; on the other hand a rotation around the [001] axis beyond the critical value $\left(>2^{\circ}\right)$ [4], leads to an absence of the reflected beam. We shall note an elongation of the imaged cells along the [001] axis. The local lattice rotations $\delta \theta$ between two adjacent cells around the [001] axis were determined by BergBarrett displacement [4]; they increase with the strain $\varepsilon$ and are given table $I$. The rotations $\Delta \theta$ around the same axis determined from back reflexion Laue pattern are given in table II. The latter rotations are indeed

TABLE I

CX sample : lattice rotations determined by BergBarrett displacement contrast.

$\delta \theta=$ local rotation around the [001] axis between two adjacent cells.

$\begin{array}{ccccc}\varepsilon= & \text { strain. } \\ \varepsilon & 4 \% & 10 \% & 16 \% & 20 \% \\ & - & - & - & - \\ \delta \theta & <24^{\prime} & 10^{\prime} & 35^{\prime} & >2^{\circ} \\ & & \text { to } 24^{\prime} & \text { to } 70^{\prime} & \end{array}$

TABLE II

CX sample : lattice rotations determined from back reflexion Laue pattern.

$\Delta \theta=$ maximum cell misorientation around the [001] axis over a $1.5 \mathrm{~mm}$ diameter area.

$\varepsilon=$ strain

\begin{tabular}{cccc}
$\varepsilon$ & $8 \%$ & $18 \%$ & $28 \%$ \\
$\overline{\Delta \theta}$ & $\overline{3}$ & - & - \\
\hline $3^{\circ}$ & $10^{\circ}$ & $20^{\circ}$
\end{tabular}

more important than the former for they represent the maximum cell desorientation over a $1.5 \mathrm{~mm}$ diameter area.

3.2 Етсн PITTING. - 3.2.1 Substructure change with creep. For the $\mathrm{C}$ samples the features of the substructure are the same all over the sample (Fig. 3)

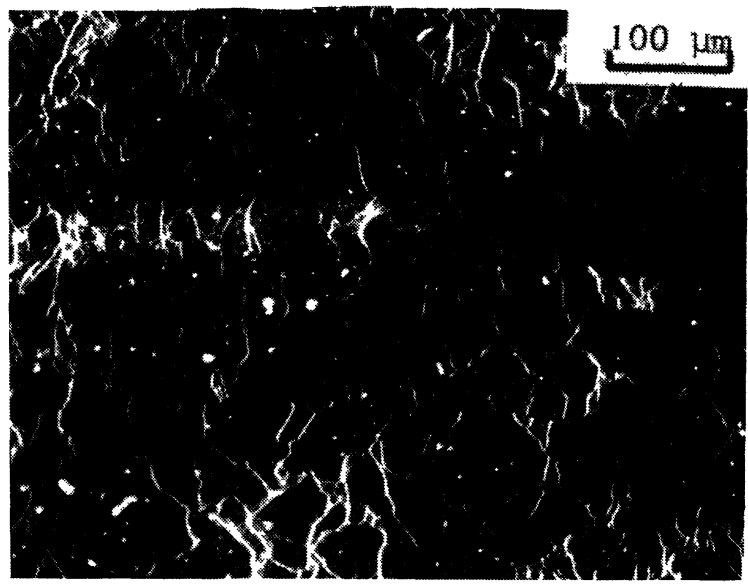

FIG. 3. - Etch pits on the plane face of a $34 \%$ strained C sample. at any moment of the creep test. A progressive cell formation leads to a steady state creep structure formed of well defined equiaxed cells of about $50 \mu \mathrm{m}[4]$.

The CX samples exhibit different features of the substructure in different parts of the sample and also two kinds of cells during the transient creep : figure $4 a$ shows the central part of a plane face, we can observe large cells and small ones elongated along the $\langle 100\rangle$ directions. A biaxed cell structure with uniform features and only one kind of cells appears for the same face in the steady state (Fig. $4 b$ ) ;

a)



b)



Fig. 4. - Etch pits on the plane face of a CX sample : change in substructure after $a) \varepsilon \simeq 14 \%$ (central part); $b) \varepsilon \simeq 50 \%$.

the boundaries are parallel to the $\langle 100\rangle$ directions. This observations can be compared to that of Hasegawa et al. $[9,10]$ who found for copper in the earlier transient stage two kinds of cells although differently distributed : regions of dense cells alternate with regions of large cells whereas we find a mixture of these two kinds of cells. When creep proceeds dense cells polygonize giving rise to coarse cells this evolution being very similar to the schematic description given by Takeuchi and Argon [11]. 
3.2.2 Relation between substructure and heterogeneity of deformation. - We found a fairly good homogeneity of the substructure for the $\mathrm{C}$ samples while the substructure features of the $\mathrm{CX}$ samples were very heterogeneous. Micrograph $5 a$ ) is the central part of the plane face of a $20 \%$ strained CX samples ; it shows a uniform biaxed cell structure similar to that of the steady state creep. Micrograph $5 b$ ) is an end region of the plane face of a $20 \%$ strained CX sample ; we can clearly observe elongated cells typical of the transient creep. These two kinds of structures in different localities of the same CX sample can be correlated to the deformation maps of Bretheau et Dolin [3] : for a $17 \%$ strained CX sample, the highest local strain found is about $35 \%$ in the central part where steady state must be established. Strain as low as $0 \%$ (or a few percent) can be observed at the specimen ends, which are still in the transient state.

3.2.3 Cell size observations. - A systematic study has not been undertaken about the dependence of cell size with applied stress : in the CX case the variation of stress from $150 \mathrm{~g} / \mathrm{mm}^{2}$ to $350 \mathrm{~g} / \mathrm{mm}^{2}$ (1.5 to 3.5 $\mathrm{MPa}$ ) was not enough to allow any conclusion. But it can be observed that the mean cell size is directly related to the true local strain : it is smaller in the end region (Fig. 5b) than in the central part (Fig. 5a).



b)

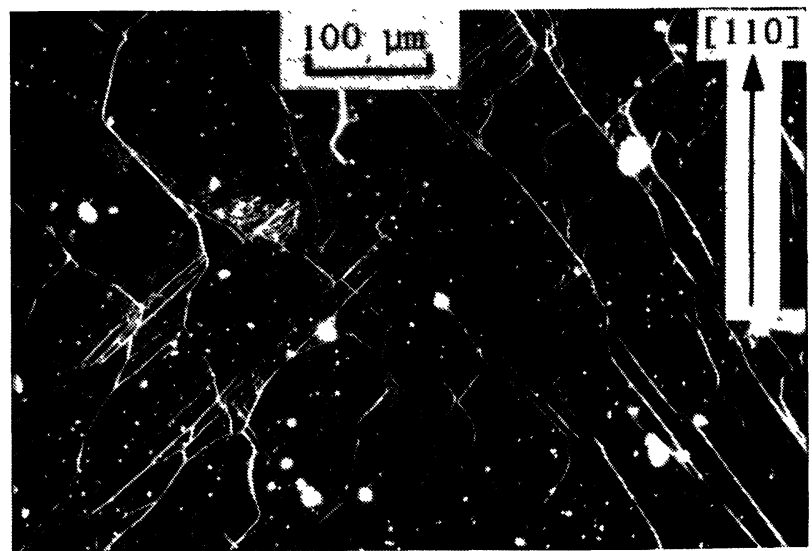

FIG. 5. - Etch pits on the plane face of a $\varepsilon \simeq 20 \% \mathrm{CX}$ sample a) central part ; $b$ ) end region.
This result is similar to that of Hasegawa et al. [9] who examined the relation between substructure and creep rate for copper single crystals and showed, in the transient stage, different types of substructures the local strain being higher in the region of coarser structure than in that of the finer one.

In the steady stage the average cell size is not any more strain dependent, it is about $50 \mu \mathrm{m}$ for a $\mathrm{C}$ sample while it is about $100 \mu \mathrm{m}$ for the plane face of a CX sample. An important difference appears when comparing the bent and plane faces of these two kinds of samples : for the $\mathrm{C}$ samples the cell substructure is quite identical for the bent and plane face (Figs. $6 a$ and $b$ ) while in the CX case we note an elongation of the imaged cells (Figs. $2 b$ and $a$ ) for the bent face.
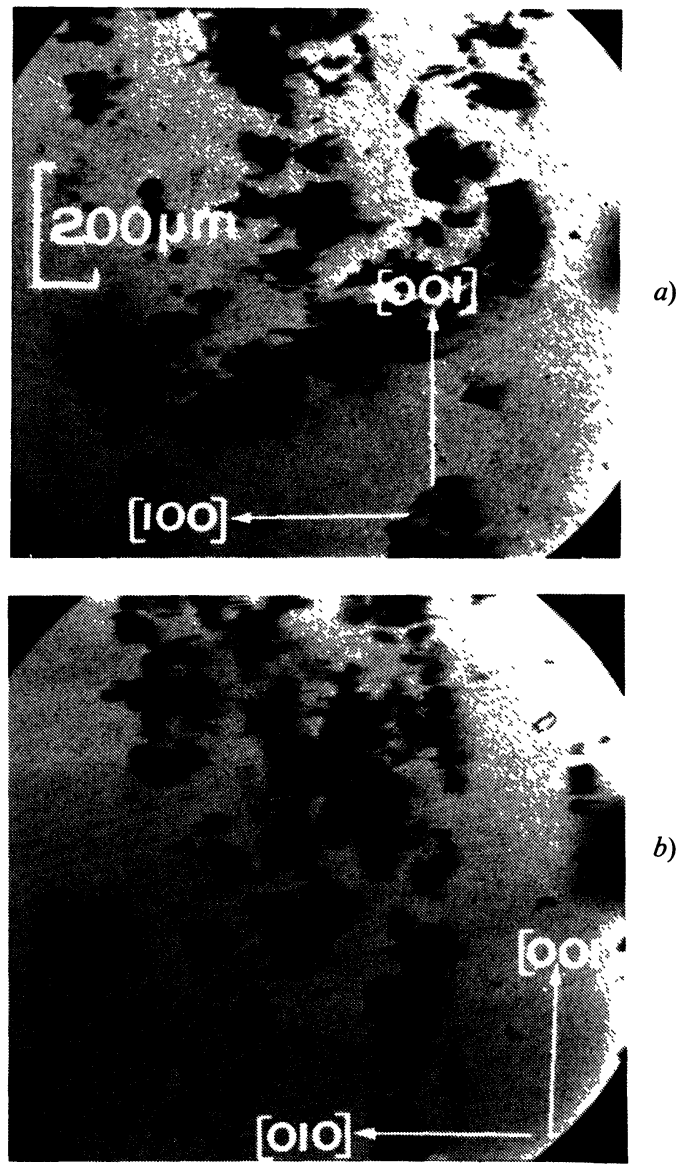

Fig. 6. - Berg-Barrett topographs of a C sample : a) (010) bent face, $[020]=\mathbf{g}, \varepsilon \simeq 24 \% ; b)(100)$ plane face, $[200]=\mathbf{g}, \varepsilon \simeq 33 \%$.

4. Discussion. - Plastic deformation of $\mathrm{Cu}_{2} \mathrm{O}$ single crystals has been obtained by high temperature compression along $\langle 001\rangle$ (C samples) and $\langle 110\rangle$ (CX samples).

The geometry of glide is not very different in chese creep tests, in both cases two glide planes are mainly activated : for $\mathrm{C}$ samples four $\{110\}\langle 1 \overline{1} 0\rangle$ glide planes have been observed at lower tempe- 
ratures $[1,12]$ while two planes are mainly activated during high temperature creep [2-4]. For CX samples four $\{011\}$ glide planes have been observed at lower temperatures while two $\{010\}$ planes appear when the temperature increases $[1,12]$ and become dominant for high temperature creep (Fig. $2 b$ ).

Different mechanical behaviours have been observed during creep [2] : creep curves (creep rate versus deformation) are dissimilar during the transient stage for $\mathrm{C}$ and $\mathrm{CX}$ samples, the steady state being reached earlier for the former than for the latter.

Microstructure confirmed these different behaviours : in the steady state creep of the $\mathrm{CX}$ samples the [001] rotation axis is parallel to the intersection of the two active glide planes; the cells are roughly parallelepipedic with mainly four tilt walls parallel to the glide planes (direct observation) and two twist walls (geometric necessity). In the $C$ case the walls do not seem anymore to be geometrically correlated to the glide planes. This difference of microstructure is supported by the comparison of the bent faces : figure $2 b$ shows elongated cells in the CX case while figure $6 a$ shows equiaxed cells in the $\mathrm{C}$ case.

The creep substructure of $\mathbf{C}$ samples is formed of equiaxed cells and is very similar to that observed in $\mathrm{MgO}$ [13]. On the other hand the substructure of $\dot{\mathrm{CX}}$ samples is very similar to that observed in
$\mathrm{NaCl}$ and $\mathrm{AgCl}[14,15]$. The usual description of substructure formation in $\mathrm{NaCl}$ and $\mathrm{AgCl}$ during creep takes into account only two orthogonal glide systems assuming the other pair is blocked up at the beginning of the deformation. The CX samples present the ideal case of a double glide; so it seems very normal to find a strong similarity between $\mathrm{CX} \mathrm{Cu}_{2} \mathrm{O}, \mathrm{NaCl}$ and $\mathrm{AgCl}$. In the $\mathrm{MgO}$ case four glide systems were needed to explain the substructure formation, the interaction of the oblique systems being very important; it is probably so for the $\mathrm{C}$ samples where the contribution of four systems is proposed.

So, two different glide systems can easily be activated in cuprous oxide when the stress is applied along $\langle 100\rangle$ (C samples) or along $\langle 110\rangle$ (CX samples). Two orthogonal $\{100\}\langle 001\rangle$ glide systems seem to operate in the $\mathrm{CX}$ case giving rise to parallelepipedic cells while four $\{110\}\langle 1 \overline{1} 0\rangle$ systems probably operate in the $\mathrm{C}$ case. The problem is to know why four glide systems are needed by $\mathrm{C} \mathrm{Cu}_{2} \mathrm{O}$ or $\mathrm{MgO}$ samples to get deformed while only two glide systems are needed by $\mathrm{NaCl}$ or $\mathrm{AgCl}$ with the same geometry of deformation.

Acknowledgments. - The authors wish to acknowledge Dr. J. Castaing and Pr. J. Philibert for continuous interest and useful comments on this work.

\section{References}

[1] Martinez-Clemente, M., Bretheau, T., Castaing, J., $J$. Physique 37 (1976) 895.

[2] Bretheau, T., Marhic, C., Spendel, M., Castaing, J., Phil. Mag. 35 (1977) 1473.

[3] Bretheau, T., Dolin, C., J. Mat. Sci. 13 (1978) 587.

[4] Fries, E., Marhic, C., Bretheau, T., J. Physique Colloq. 37 (1976) C7-572.

[5] Schmidt-Whitley, R. D., Martinez-Clemente, M. et RevCOleVSCHI, A., J. Cryst. Growth 23 (1974) 113.

[6] Schmidt-Whitley, R. D., Martinez-Clemente, M., CasTAING, J., Phys. Status Solidi (a) 27 (1975) 107.

[7] Newkirk, J. B., Trans. Met. Soc. A.I.M.E., U.S.A. 215 (1959) 483.
[8] Wilkens, M., Can. J. Phys. 45 (1967) 567.

[9] Hasegawa, T., Karashima, S., Hasegawa, R., Met. Trans. 2 (1971) 1449.

[10] Hasegawa, T., Hasegawa, R., Karashima, S., Trans. Jpn. Inst. Metals 11 (1970) 101.

[11] Takeuchi, S., Argon, A. S., J. Mat. Sci. 11 (1976) 1542.

[12] Audoundo, A., Thèse $3^{\mathrm{e}}$ cycle, Paris (1978).

[13] Huther, W., RePPICH, B., Phil. Mag. 28 (1973) 363; Phil. Mag. 30 (1974) 1009.

[14] Poirier, J. P., Phil. Mag. 26 (1972) 701.

[15] Pontikis, V., Thèse d'Etat, Paris (1977). 